\title{
EMPLOYEE PERFORMANCE ANALYSIS AT THE REGIONAL FINANCIAL AND ASSET MANAGEMENT AGENCY OF MUSI RAWAS REGENCY
}

\author{
Yohanes Susanto and Yuliana \\ Fakultas Ekonomi Universitas Bina Insan, Prgram Magister Manajemen \\ E-mail: susantoyohanes60@gmail.com, yulianaacep@gmail.com
}

\begin{abstract}
This study aims to analyze the factors that affect employee performance at the Regional Financial and Asset Management Agency, Musi Rawas Regency, South Sumatra. This research is a quantitative study with a total population of 60 respondents. The results of the analysis show that the variables of Competence, Leadership and Motivation simultaneously have a positive and significant effect on performance. Moreover, Competence (X1) Leadership (X2) and Motivation (X3) partially have a positive and significant effect on employee performance (Y). However, the Leadership variable has a very dominant influence on performance. It is recommended that the performance of employees at the Regional Financial and Asset Management Agency of Musi Rawas Regency to be improved. The role of leadership can also be used as a benchmark for the success of a team's work in public services, delegation of authority and supervision. It is also recommended that the leader's task evaluation be carried out periodically. In addition, efforts to improve employee competence are a strategic step in increasing employee motivation.
\end{abstract}

Keywords: competence; leadership; work motivation; employee performance

\section{ANALISIS KINERJA PADA BADAN PENGELOLA KEUANGAN DAN ASSET DAERAH KABUPATEN MUSI RAWAS}

\begin{abstract}
ABSTRAK. Penelitian ini bertujuan untuk menganalisis faktor yang mempengaruhi Kinerja pegawai pada Badan Pengelola Keuangan dan Aset Daerah Kabupaten Musi Rawas Sumatera selatan. Penelitian ini adalah penelitian kuantitatif dengan jumlah populasi penelitian sebanhyak 60 responden. Hasil analisis menunjukkan bahwa secara simultan variabel Kompetensi, Kepemimpinan dan Motivasi berpengaruh positif dan signifikan terhadap Kinerja. Selain itu, Kompetensi $\left(\mathrm{X}_{1}\right)$ Kepemimpinan $\left(\mathrm{X}_{2}\right)$ dan Motivasi $\left(\mathrm{X}_{3}\right)$ secara parsial berpengaruh positif dan signifikan terhadap kinerja karyawan $(\mathrm{Y})$. Namun variabel Kepemimpinan mempunyai pengaruh sangat dominan terhadap kinerja. Disarankan agar kinerja pegawai pada Badan Pengeloala Keuangan dan Asset daerah Kabupaten Musi Rawas dapat ditingkatkan. Peran kepemimpinan juga dapat dijadikan tolak ukur keberhasilan kerja sebuah tim dalam pelayanan publik, pendelegasian wewenang dan pengawasan. Evaluasi tugas pimpinan juga disarankan untuk dilakukan secara berkala. Selain itu, upaya meningkatkan kompetensi pegawai merupakan langkah strategis dalam meningkatkan motivasi pegawai.
\end{abstract}

Kata kunci: kompetensi; kepemimpinan; motivasi kerja; kinerja pegawai

\section{INTRODUCTION}

The existence of public organization today increasingly receives sharp attention, especially concerning the public satisfaction with services provided by these organizations. Public organizations are currently required to be able to create innovative bureaucracies so they are able to overcome problems in order to provide satisfactory public services for the community. Satisfactory public services require a strong commitment, adequate apparatus service competence, motivation from the leadership towards subordinates and various other supporting aspects. In line with this, human resources apparatus who have expertise and skills are needed. Their presences are expected to increase the productivity and performance of the government bureaucracy. However, the reality shows that the performance of human resources apparatus at The Regional Financial and Asset Management Agency of Musi Rawas Regency is still less than optimal. Thus, this study is directed to analyse the factors affecting the performance of employees of The Regional Financial and Asset Management Agency in Musi Rawas Regency.

According to (Harahap \& Tirtayasa, 2020), performance is the result of a process which is referred and measured during a period of time based on predetermined conditions. Various problems that exist today are closely related to the performance of human resources apparatus. This is in line with the theory proposed in (Badrianto \& Ekhsan, 2020) that employee performance is the result produced by specific work function or the activity on specific job and the result of work is the the result of ability, skills and goals achived. Another idea proposed by (Ardiansyah \& Sulistiyowati, 2018) that employee performance is how person is expected to behave in accordance with the task assigned to them. According to (Dahlan \& Dewasiri, 2019), employee performance takes responsibility for the success of the organization. Previous work (Ngwa, Adeleke, Agbaeze, Ghasi, \& Imhanrenialena, 2019) stated that performance 
influenced by some factors and one of them is the quantity of assignment which can be completed by someone in one day of work. Performance is also stated as an action to do the assignment and work achievement (Emil \& Albetris, 2019). Employee performance must also be managed effectively to achieve productivity which leads to the achievement of success both in organization and individual (Andriani, Kesumawati, \& Kristiawan, 2018). A reward for exemplary employees and the provision of punishment for employees who make mistake in doing their tasks can improve employee performance in a better level (Novarini \& Imbayani, 2019).

Based on the Civil Servant Professionality Index (ASN IP) data obtained from the staffing section of The Regional Financial and Asset Management Agency of Musi Rawas Regency, it can be identified that there are problems realated to employee performance including the failure to achive the goals and work standard that have been set. This is indicated by the low achievement of the professionality index. The average ASN IP value of employees is in the range of 69.61 with a low predicate. According to BKN Regulation Number 8 of 2019, the measurement of professionalism index is an instrument used to measure quantitatively the level of professionalism of ASN employees. The result can be used as a basis for assessment and evaluation in effort to develop ASN professionalism. The criteria used to measure the level of professionalism of ASN includes the dimensions of educational qualifications, competencies, performance achievements and employee discipline.

The productivity and performance of civil servants require human resources that are qualified and competent with adequate expertise and skills. However, the reality shows that the performance of human resources available at the Regional Financial and Asset Management Agency of Musi Rawas Regency is still less than optimal. There are still employees who have performance achievements below the set standards which equals to $55.26 \%$. Thus, employees are less than optimal in carrying out their duties and work. Furthermore, the high percentage of employees who get low and very low scores for employee competency assessment is $42.11 \%$. The low achievement of ASN IP of The Regional Financial and Asset Management Agency of Musi Rawas Regency in 2019 was mainly because of the fact that there were many employees who got very low professionality index assessment (PIP) score of $34.21 \%$. The details of the achievement of ASN IP can be seen as follow:
Table 1. The Achievement of ASN IP of The Regional Financial and Asset Management Agency of Musi Rawas Regencyin 2019

\begin{tabular}{llcr}
\hline No & $\begin{array}{c}\text { Category/IP } \\
\text { Predicate }\end{array}$ & $\begin{array}{c}\text { The number } \\
\text { of employees }\end{array}$ & Percentage \\
\hline 1 & Very high & 3 & $7,89 \%$ \\
2 & High & 7 & $18,42 \%$ \\
3 & Medium & 8 & $21,05 \%$ \\
4 & Low & 7 & $18,42 \%$ \\
5 & Very Low & 13 & $34,21 \%$ \\
\hline & Total & 38 & $100 \%$ \\
\hline & & Source: BPKAD 2019 IP Document
\end{tabular}

Table 1 shows that the overall score of ASN IP produced by The Regional Financial and Asset Management Agency of Musi Rawas Regency in 2019 is still in a low level. The very low predicate obtained as $34.21 \%$ ( 13 employess) and low predicate as much as $18.42 \%$ ( 7 employees). Meanwhile, the employees whose IP are very high are only obtained as $7.89 \%$ ( 3 employess) which is followed by high predicate as much as $18.42 \%$ and medium predicate as much as $21.05 \%$ ( 8 employess).

The low level of ASN IP caused by the fact that there are many employees whose performances are still below the set standard. The range of 76-90 was obatined by as much as $55.26 \%$ employees. The percentage can be seen in the figure below:

\section{Percentage}

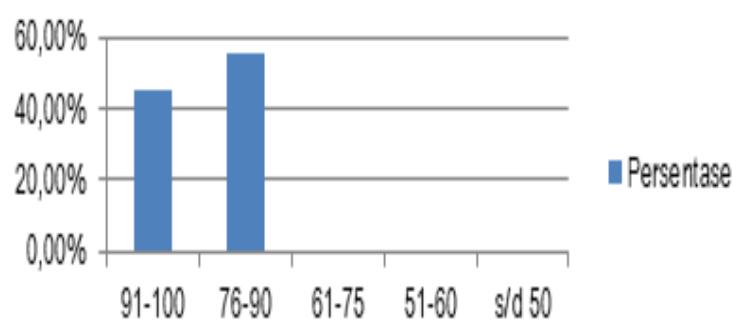

Figure 1. The percentage of the ASN IP achievement of The Regional Financial and Asset Management Agency of Musi Rawas Regencyin 2019. Source: IP BPKAD Data of 2019

From Figure 1, it can be seen that the percentage of the ASN IP achievement of The Regional Financial and Asset Management Agency of Musi Rawas Regency in 2019 is only $44.74 \%$ (17 employess) of those who meet the standard target of 91-100. Furthermore, as much as $55.26 \%$ or 21 people only get the ASN IP score of 76-90. The lackof accuracy of employees in finishing their work has been said as the main cause of this low achievement as stated by the head of the personnel subsection. 
As an organization that has responsibility for managing financial sector in local area, it requires human resources apparatus with formal educational qualifications related to financial management. The lack of employee knowledge of financial management causes empployees to be less than optimal in carrying their duties. Data on the achievement of the ASN BPKAD IP in 2019 showed that there are no employees who have master's degree and as much as $15.79 \%$ employees have senior high school and diploma qualifications. It is also stated in (Dahlan \& Dewasiri, 2019) that performance is the main indicator in measuring human resources effectivity in an organization. Thus, outstanding employees will give economic success and good reputation desired by the organization. It is also argued by (Santoso \& Riyanto, 2020) that employee performance is the result achieved by employees in implementing the duties which are their responsibility, presenting the results and giving useful contribution to the organization or company.

In addition to educational qualification, competence issue is very important in supporting employee performance. According to (Rahardja, Moein, \& Lutfiani, 2018), competence is a knowledge, skill, and ability achieved by a person which are part of their current existence so that they can perform cognitive function effectively and satisfactorily. Furthermore, another suggestion came from (Nguyen, Yandi, \& Mahaputra, 2020) who stated that competence is a crucial thing for an organization in managing human resources. It is also stated that competence can give advantage to many parties, employee, organization, industry or even individual (Kang \& Lee, 2021). In the research conducted by (Parashakti, Fahlevi, Ekhsan, \& Hadinata, 2020), competence is interpreted as a basic ability and work quality required by someone in doing their assignment well.

The Regulation of BKN Number 8 of 2019 stated that competence dimension used to measure the data of competence development that has been followed by civil servants who have conformity in carrying out their duties. The competence dimension is given a maximum weight of 40 (very high). Based on the IP of civil servants obtained from The Regional Financial and Asset Management Agency of Musi Rawas Regency, it can be identified that the achievement of employee competence is still in a low level. The percentages are presented in Table 2 .

Table 2 shows that there are only $26.32 \%$ or 10 employees who get very high score for competence. As much as $23.68 \%$ get high score and as much as $7.89 \%$ get medium score for competence. As much as $42.11 \%$ or 16 employees then get low and very low scores for competence. This proves that the competence issue needs more attention since competence is an important factor affecting the employee performance that can maximize the performance in a better way. This is in line with the study conducted by (Tarigan \& Setiawan, 2020) which stated that competence is someone's ability to produce better performance in a work place, including the ability of someone to transfer and apply the knowledge in a new situation so that it can provide an advantage.

Table 2. The percentage of competence achievement of The Regional Financial and Asset Management Agency of Musi Rawas Regency in 2019

\begin{tabular}{rlcr}
\hline No & Score value & $\begin{array}{c}\text { The number of } \\
\text { employees }\end{array}$ & \multicolumn{1}{l}{$\%$} \\
\hline 1 & Very high & 10 & $26,32 \%$ \\
2 & High & 9 & $23,68 \%$ \\
3 & Medium & 3 & $7,89 \%$ \\
4 & Low & 10 & $26,32 \%$ \\
5 & Very low & 6 & $15,79 \%$ \\
\hline & Total & 38 & $100 \%$ \\
\hline
\end{tabular}

Source: IP Document of BPKAD 2019

This competence issue is due to the fact that there are still many employees (the percentage is $68.42 \%$ or 26 employess) who have not yet followed the obligation to develop human resources competence, such as participating in a technical training which support the duties and task. Competence also defined as an ablity based on skill and knowledge supported by work behaviour and the implementation in doing the task and duty (Ardiansyah \& Sulistiyowati, 2018). The lack of technical expertise makes employees have less skill in using tools both hardware and software as well as facilities which support their work. As a result, it makes a lot of time in finishing the task and the result is not up to the expected standard. The percentage of employees who have not followed the development of human resources competence can be seen in Figure 2:

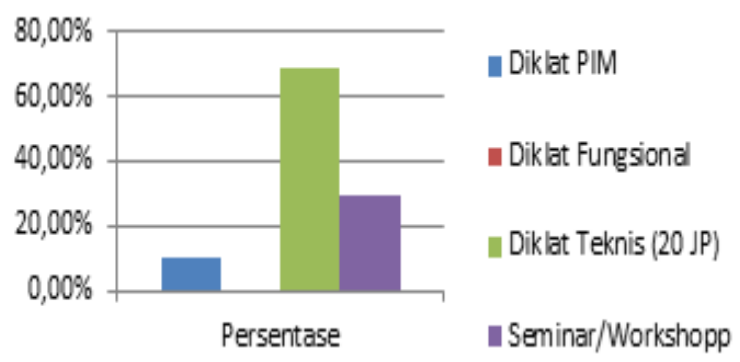

Figure 2. The percentage of employees who have not followed the development of human resources competence. Source: IP Document of BPKAD 2019 
Figure 2 shows that the employees who have not followed the technical training reaches $68.42 \%$ or 26 employees from 38 civil servants in 2019. There are also $10 \%$ of staff who have not followed the PIM training, while the employees who have not followed the workshop are $28.95 \%$ or 11 employees from 38 civil servants.

In addition to unoptimal competence of human resource, the issue of leadership and motivation also give an effect. The lack of guidance in completing the task and communication between leader and employees are allegedly one of the causes of low motivation. It is stated that leadership is an ability owned by someone to influence someone else to do a better work in order to achieve the goals of companies or organizations (Prestia, 2021). In addition, leadership is declared as a process conducted by a leader to influence, coordinate and guide another party in an organization or a company to achieve determined goals (Budiman \& Barata, 2018). Thus, leadership is absolutely necessary in achieving the goals of an organization.

It is important to make sure that all activities are carried out with an aligned direction and integrated each other effectively and efficiently. It is explained that leadership is an ability to influence, motivate and guide an individual or group of people to achive the goals (Emil \& Albetris, 2019). Leadership is also explained as a process to connect or to give good example to the followers through communication of process in order to achieve the goals of an organization (Ahmadi \& Sulistyono, 2019). Furthermore, a leadership is someone's ability to influence someone else to do something (Krapfl \& Kruja, 2015).

Apart from leadership issue, the implementation of staff positioning and promotion as a form of human resource development for carrer planning has not been optimaly implemented. There are many employees with a working period of more than 5 years who have not got a promotion yet. This can cause employees to feel bored and less-enthusiastic in doing their job resulting in the decline of their productivities. It is mentioned that motivation is a psychological process that affect someone's persistence to achieve goals (Ardhani \& Ratnasari, 2019). Moreover, it is explained that motivation is a psychological condition which appears due to the encouragement to meet the need (Kim \& Beehr, 2020). It is also stated that motivation is an effort that can encourage someone to do the desired action (Basalamah \& As'ad, 2021).

The external constraint that has been found so far is the problem of availability of the required information or data. Considering The Regional
Financial and Asset Management Agency of Musi Rawas Regency is responsible in managing local financial sector, this organization needs the data from working partner such as The Regional Apparatus Organization within the Musi Rawas Regency Government. However, the data frequently does not arrive on time, while the demand for fast and accurate report submission is very high. The central regulation also often changed with rapid technological development and increasingly high demand for services to partners (OPD) that all have an effect in the form of high pressure on employees which decreases work enthusiasm.

Based on the discussion above, it can be inferred that competence, leadership and motivation are all related to employee performance. It has also been explained that the perfomence of civil servants at The Regional Financial and Asset Management Agency of Musi Rawas Regency is still below the expected standard. Thus, this study will be the first work that will investigate in detail the impact of competence, leadership and motivation on work performance of civil servants at The Regional Financial and Asset Management Agency of Musi Rawas Regency.

\section{METHOD}

The problem that will be discussed in this study is how the influence of competence, leadership and work motivation on the performance of the employees of the Regional Financial and Asset Management Agency of Musi Rawas Regengy. This study is an empirical test that will test the predetermined hypothesis and a quantitative data analysis used was performed by multiple linear regression analysis method using satistical product and service solutions (SPSS) program with the aim of testing the predetermined hypothesis. The purpose of testing the hypothesis is to provide an overview of the variables that affect employee performance at the Regional Financial and Asset Management Agency of Musi Rawas Regency which includes the variables of Competence, Leadership and Work Motivation. The population in this study were 65 employees of the Regional Financial and Asset Management Agency of Musi Rawas Regency. The sampling technique in this study was based on total sampling method as explained in (Sugiyono, 2018). Total sampling is a sampling technique where all members of the population are sampled. Thus, the size of sample is equivalent to the size of population. The demographic profile of the respondents is shown in Table 3. 
Table 3. Demographic profile of respondents

\begin{tabular}{|c|c|c|c|}
\hline Gender & Age & Formal education & Marital status \\
\hline MALE & 56 & Bachelor's degree/Diploma 4 & Married \\
\hline FEMALE & 53 & Bachelor's degree/Diploma 4 & Married \\
\hline MALE & 52 & Bachelor's degree/Diploma 4 & Married \\
\hline FEMALE & 45 & Bachelor's degree/Diploma 4 & Married \\
\hline FEMALE & 41 & Bachelor's degree/Diploma 4 & Married \\
\hline MALE & 46 & Bachelor's degree/Diploma 4 & Married \\
\hline FEMALE & 30 & Bachelor's degree/Diploma 4 & Married \\
\hline MALE & 48 & Diploma 3 & Married \\
\hline MALE & 43 & Highschool/Diploma 1/Diploma 2 & Married \\
\hline MALE & 40 & Highschool/Diploma 1/Diploma 2 & Married \\
\hline MALE & 33 & Bachelor's degree/Diploma 4 & Married \\
\hline MALE & 45 & Master's degree & Single \\
\hline MALE & 49 & Master's degree & Married \\
\hline FEMALE & 42 & Bachelor's degree/Diploma 4 & Married \\
\hline MALE & 48 & Master's degree & Married \\
\hline FEMALE & 49 & Highschool/Diploma 1/Diploma 2 & Married \\
\hline MALE & 36 & Bachelor's degree/Diploma 4 & Single \\
\hline FEMALE & 46 & Master's degree & Married \\
\hline FEMALE & 32 & Bachelor's degree/Diploma 4 & Married \\
\hline FEMALE & 45 & Master's degree & Married \\
\hline FEMALE & 48 & Bachelor's degree/Diploma 4 & Married \\
\hline MALE & 43 & Diploma 3 & Married \\
\hline FEMALE & 45 & Bachelor's degree/Diploma 4 & Married \\
\hline FEMALE & 42 & Bachelor's degree/Diploma 4 & Married \\
\hline FEMALE & 53 & Bachelor's degree/Diploma 4 & Married \\
\hline FEMALE & 46 & Highschool/Diploma 1/Diploma 2 & Married \\
\hline MALE & 39 & Master's degree & Married \\
\hline MALE & 40 & Bachelor's degree/Diploma 4 & Married \\
\hline MALE & 48 & Bachelor's degree/Diploma 4 & Married \\
\hline MALE & 40 & Bachelor's degree/Diploma 4 & Married \\
\hline FEMALE & 58 & Master's degree & Married \\
\hline FEMALE & 44 & Master's degree & Married \\
\hline FEMALE & 47 & Bachelor's degree/Diploma 4 & Married \\
\hline FEMALE & 35 & Bachelor's degree/Diploma 4 & Married \\
\hline FEMALE & 24 & Bachelor's degree/Diploma 4 & Single \\
\hline MALE & 28 & Bachelor's degree/Diploma 4 & Married \\
\hline MALE & 34 & Bachelor's degree/Diploma 4 & Married \\
\hline MALE & 58 & Bachelor's degree/Diploma 4 & Married \\
\hline FEMALE & 30 & Bachelor's degree/Diploma 4 & Married \\
\hline MALE & 35 & Highschool/Diploma 1/Diploma 2 & Single \\
\hline MALE & 36 & Bachelor's degree/Diploma 4 & Married \\
\hline FEMALE & 35 & Bachelor's degree/Diploma 4 & Married \\
\hline MALE & 38 & Bachelor's degree/Diploma 4 & Married \\
\hline FEMALE & 36 & Bachelor's degree/Diploma 4 & Married \\
\hline MALE & 37 & Bachelor's degree/Diploma 4 & Married \\
\hline MALE & 35 & Bachelor's degree/Diploma 4 & Married \\
\hline MALE & 33 & Bachelor's degree/Diploma 4 & Married \\
\hline MALE & 35 & Bachelor's degree/Diploma 4 & Married \\
\hline MALE & 34 & Bachelor's degree/Diploma 4 & Married \\
\hline
\end{tabular}

Employee Performance Analysis at the Regional Financial and Asset Management Agency of Musi Rawas Regency (Yohanes Susanto and Yuliana) 


\begin{tabular}{cccc}
\hline MALE & 32 & Bachelor's degree/Diploma 4 & Married \\
MALE & 30 & Bachelor's degree/Diploma 4 & Single \\
MALE & 35 & Bachelor's degree/Diploma 4 & Married \\
MALE & 37 & Bachelor's degree/Diploma 4 & Married \\
FEMALE & 28 & Highschool/Diploma 1/Diploma 2 & Married \\
MALE & 30 & Bachelor's degree/Diploma 4 & Single \\
MALE & 34 & Bachelor's degree/Diploma 4 \\
FEMALE & 26 & Bachelor's degree/Diploma 4 & Married \\
MALE & 25 & Bachelor's degree/Diploma 4 & Single \\
FEMALE & 25 & Bachelor's degree/Diploma 4 & Married \\
MALE & 27 & Bachelor's degree/Diploma 4 & Single \\
\hline
\end{tabular}

\section{RESULT AND DISCUSSION}

\section{Statistical Test Result}

\section{Partially significant influence of competence} on employee performance at The Regional Financial and Asset Management Agency of Musi Rawas Regency

The analysis on regression test result was conducted using SPSS to measure the influence between compentency variable (X1) and employee performance. The obtained data is presented in Table 4 below:

Table 4. Simple regression of competence variables

\begin{tabular}{|c|c|c|c|c|c|c|}
\hline & \multirow{2}{*}{$\begin{array}{c}\text { Model } \\
\text { B }\end{array}$} & \multicolumn{2}{|c|}{$\begin{array}{c}\text { Unstandardized } \\
\text { Coefficients } \\
\end{array}$} & \multirow{2}{*}{$\begin{array}{l}\text { Standardized } \\
\text { Coefficients }\end{array}$} & \multirow{2}{*}{$\mathrm{t}$} & \multirow{2}{*}{ sig } \\
\hline & & $\begin{array}{l}\text { Std. } \\
\text { Error }\end{array}$ & Beta & & & \\
\hline \multirow[t]{2}{*}{1} & (Constant) & 47.718 & 8.927 & & & \\
\hline & Competence & .380 & .148 & .320 & 2.574 & 0,13 \\
\hline
\end{tabular}

Based on the Table 4 above, the obtained $b_{1}$ is 0,380 , while a value (constant) is 47,718 . Those two values are then inputed to the linear regression equation as follows:

$$
Y=47,718+0,380 X_{1}
$$

The regression equation indicates that competence variable (X1) has a separate influence on employee performance $(\mathrm{Y})$.

a. The constant value, which is 47,718 , means that if there is no competence variable or the value is 0 , then the consistency value of employee performance of The Regional Financial and Asset Management Agency of Musi Rawas Regency is 47,718.

b. The regression coefficient of competence variable (X1) or b1 is 0,380 , means that if there is an increase in the competence variable (X1) by one unit, it will increase employee performance $(\mathrm{Y})$ by 0,380 unit. On the other hand, if the competence regression value decreases by one unit, then employee performance is also predicted to decrease by 0,380 unit. Therefore, it can be concluded that competence has a direct correlation on employee performance.

From the test data inputed into the variable regression model, it is obtained that the t-count value is 2,574 and t-table is 2,001 (t-table value $\mathrm{n}=58$ ), $\mathrm{df}$ (n-3) $60-2=58$ is 2,001 . Therefore, it indicates that if the criteria are in accordance with $\mathrm{t}$-count $>\mathrm{t}$-table, then $\mathrm{Ho}$ is declined and $\mathrm{Ha}$ is accepted. It means that there is influence of competence on employee performance of The Regional Financial and Asset Management Agency of Musi Rawas Regency. This finding is also aligned with the result in (Pasae, 2021) which stated that there is a relationship between competence and employee work performance.

\section{Partially significant influence of leadership} on employee performance at The Regional Financial and Asset Management Agency of Musi Rawas Regency

A simple regression test was carried out using SPSS to measure the influence between leadership variable (X2) and employee performance. The output data of SPSS is presented in Table 4 below:

Table 5. Simple regression of leadership variable

\begin{tabular}{|c|c|c|c|c|c|c|}
\hline & \multirow{2}{*}{$\begin{array}{c}\text { Model } \\
\text { B }\end{array}$} & \multicolumn{2}{|c|}{$\begin{array}{c}\text { Unstandardized } \\
\text { Coefficients }\end{array}$} & \multirow{2}{*}{$\begin{array}{c}\text { Standardized } \\
\text { Coefficients }\end{array}$} & \multirow{2}{*}{$\mathrm{t}$} & \multirow{2}{*}{ sig } \\
\hline & & $\begin{array}{l}\text { Std. } \\
\text { Error }\end{array}$ & Beta & & & \\
\hline \multirow[t]{2}{*}{1} & (Constant) & 39.732 & 6.418 & & & \\
\hline & Leadership & .416 & .086 & .537 & 4,844 & 000 \\
\hline
\end{tabular}

a. Dependent Variable: performance

Based on Table 5, the obtained b1 value is 0,416 and a value (constant) is 39,732 . These two values are inputed into the equation of simple linear regression as follows:

$\mathbf{Y}=39,732+0,416 \mathbf{X}_{2}$

The regression equation shows that leadership variable (X2) has a separate influence on employee performance $(\mathrm{Y})$. 
a. The constant value is 39,732 , means that if there is no leadership variable, then consistency value of employee performance of The Regional Financial and Asset Management Agency of Musi Rawas Regency is 39,732 .

b. The regression coefficient of leadership variable (X2) or b1 is 0,416 , means that if there is an increase on leadership variable in an amount of one unit, then it will increase employee performance in an amount 0,416 unit. On the other hand, if the leadership regression is decreased by an amount of one unit, then employee performance is predicted decreased by an amount of 0,416 unit. Therefore, leadership has a direct relationship on employee performance.

c. From the test data of independent variable inputed into regression model, it can be found that t-count is 4,844 and $\mathrm{t}$-table is 2,001 ( $\mathrm{t}$-table value $\mathrm{n}=$ 58) $\mathrm{df}(\mathrm{n}-3) 60-2=58$ is 2,001 , then if the criteria are in accordance with $\mathrm{t}$-count $>\mathrm{t}$-table, then $\mathrm{Ho}$ is declined and $\mathrm{Ha}$ is accepted. It means that there is an influence of leadership on employee performance of The Regional Financial and Asset Management Agency of Musi Rawas Regency. Similarly, it is also found that leadership has positive impact on employee performance (Top, Abdullah, \& Faraj, 2020).

\section{Partially significant influence of work moti-} vation on employee performance at The Regional Financial and Asset Management Agency of Musi Rawas Regency

The simple resgression test analysis was conducted using SPSS to measure the influence between work motivation variable (X3) and employee performance (Y). The obtained data is presented in Table 6 below:

Table 6. The simple regression of motivation variable

\begin{tabular}{|c|c|c|c|c|c|c|}
\hline & \multirow{2}{*}{$\begin{array}{c}\text { Model } \\
\text { B }\end{array}$} & \multicolumn{2}{|c|}{$\begin{array}{c}\text { Unstandardized } \\
\text { Coefficients }\end{array}$} & \multirow{2}{*}{$\begin{array}{c}\text { Standardized } \\
\text { Coefficients }\end{array}$} & \multirow{2}{*}{$\mathrm{t}$} & \multirow{2}{*}{ sig } \\
\hline & & $\begin{array}{l}\text { Std. } \\
\text { Error }\end{array}$ & Beta & & & \\
\hline \multirow[t]{2}{*}{1} & (Constant) & 51.116 & 6.743 & & & \\
\hline & Motivation & .340 & .117 & .357 & 2.911 & 005 \\
\hline
\end{tabular}

Based on the Table 6 , the obtained b1 is 0,340 , while a value (constant) is 51,116 . Those two values are then inputed into simple linear regression equation:

$$
\mathbf{Y}=\mathbf{5 1 , 1 1 6}+\mathbf{0 , 3 4 0 X _ { 3 }}
$$

The regression equation indicates that motivation variable (X3) has a separate influence on employee performance $(\mathrm{Y})$. The result can be explained as follows: a. The constant value is $\mathbf{5 1 , 1 1 6}$, which means if there is no motivation variable, then the employee performance of The Regional Financial and Asset Management Agency of Musi Rawas Regency is 51,116 .

b. The regression coefficient of motivation variable (X3) or b1 is 0,340 , which means if there is an increase on the motivation variable amount of one unit, then it will increase employee performance (Y) amount of 0,340 unit. On the other hand, if the regression value of motivation decreases the amount of one unit, then employee performance (Y) is predicted to decrease by the amount of 0,340 unit. Therefore, it can be concluded that motivation provided by a leader has direct correlation on employee performance which is also aligned with the finding in (Wahyuni, Purwandari, \& Syah, 2020).

c. From the results of independent variable test which were inputed into regression model, it can be known that $\mathrm{t}$-count value is 2.911 and $\mathrm{t}$-table is 2.001 (t-table value $\mathrm{n}=58) \mathrm{df}=(\mathrm{n}-3) 60-2=58$ is 2.001, which means that the criteria is appropriate.

\section{Simultaneously significant influence between} competence and leadership on employee performance of The Regional Financial and Asset Management Agency of Musi Rawas Regency

Based on the result of regression calculation, the obtained $\mathrm{b} 1$ value $=0.252$ and $\mathrm{b} 2=0.380$, while a value is 27.218 . These values inputed into double linear regression equation as follows:

$Y=27.218+0,252 X_{1}+0,380 X_{2}$

Regression equation indicates that competence variable (X1), leadership (X2) have a joint effect on employee performance. The result can be explained as follow:

a) The constant value is $\mathbf{2 7 . 2 1 8}$ which means that if the value of competence variable and leadership do not change or the value is zero, then the consistency value of employee performance of The Regional Financial and Asset Management Agency of Musi Rawas Regency is 27.218.

b) The competence variable of regression coefficient (X1) or b1 is $\mathbf{0 , 2 5 2}$. This indicates that if the value of competence variable increases by an amount of one unit, then performance variable will change positively by an amount of $\mathbf{0 , 2 5 2}$ unit. On the other hand, if the regression value decreases by an amount of one unit, then employee performance is also predicted to decrease by an amount of 0,252 unit. Therefore, competence has direct correlation on employee performance. 
c) The regression coefficient of leadership variable (X2) or b2 is 0,380 which means that if the value of leadership variable (X2) increases by an amount of one unit, then the value of employee performance variable $(\mathrm{Y})$ will change positively by an amount of 0,380 unit. On the other hand, if regression value decreases by an amount of one unit, then employee performance is also predicted to be decreased by an amount of 0,380 unit.

d) Simultaneous test (F test) was conducted to see the effect from independent variable on dependent variable simultaneously. F-table $=60-2-1=57$, df $57=2,77$ and based on the recapitulation of the result of multiple linear regression, it is found that the calculated F-count obtained 14.109 $>\mathrm{F}_{\text {tabel }}=$ 2,77 and the simultaneous significance level of sig F is 0,000 . This indicates that simultaneously independent variables (competence and leadership) have an effect on dependent variable (performance). This finding is also supported by the result of (Sunaryo, Hardhienata, \& Suhardi, 2020) where they found that leadership and competence are positively and significantly connected to performance.

\section{Simultaneously significant influence between} competence and work motivation on employee performance of The Regional Financial and Asset Management Agency of Musi Rawas Regency

Based on the result of multiple regression calculations by using SPSS, it is obtained that the $b_{1}$ value is 0,188 and $b_{2}$ is 0,245 , while a value is 45,223 . Then, these values are inputed into multiple linear regression equation as follows:

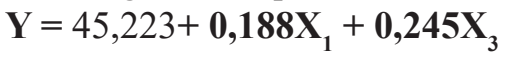

The regression equation shows that competence variable (X1) and work motivation (X3) simultaneously influence employee performance $(\mathrm{Y})$. The result of regression test can be explained as follows:

a) The constant value is 45,223 which means that if the value of competence variable and motivation do not change or the value is zero, then the consistency value of employee performance of The Regional Financial and Asset Management Agency of Musi Rawas Regency is 45,223.

b) The regression coefficient of competence variable (X1) or b1 is 0,188 . This indicates that if the value of competence variable increases by the amount of one unit, then the value of performance variable will change positively by the amount of $\mathbf{0 , 1 8 8}$ unit. On the other hand, if regression value decreases by the amount of one unit, then the employee performance is also predicted to decrease by the amount of 0,2188 unit. Therefore, it can be concluded that competence has a direct correlation on employee performance.

c) The regression coefficient of motivation (X3) is 0,245 which means that if the value of motivation variable (X3) increases by the amount of one unit, then the value of employee performance variable (Y) will change positively by the amount of 0,245 unit. On the other hand, if regression value decreases by the amount of one unit, then employee performance is also predicted to decreases by the amount of 0,245 unit.

d) Simultaneous test (F-test) was conducted to see the influence from independent variable and dependent variable. F-tabel $=60-2-1=57$, df $57=2,77$ and based on the recapitulation result of multiple linear regression test, it is obtained that the value of f-count is $4,744>\mathrm{F}_{\text {tabel }}=2,77$ and the simultaneous significance level of sig $F$ is 0,012 . This indicates that independent variables (competence and work motivation) have influence on dependent variable (performance) which also found in previous work (Suratman, Arafat, \& Eddy, 2020).

\section{Significant influence between leadership and work motivation on employee performance of The Regional Financial and Asset Management Agency of Musi Rawas Regency}

Based on the results of regression calculation, it is obtained that the $b_{1}$ value is 0,365 and $b_{2}=0,143$, while a value is 35,314 . These values inputed into multiple linear regression equation as follows: $\mathbf{Y}=$ $35,314+\mathbf{0}, 365 X_{2}+\mathbf{0}, 143 X_{3}$

This regression equation shows that leadership variable (X2) and work motivation (X3) simultaneously influence employee performance (Y). The result can be explained as follows:

a) The constant value is 35,314 which means if leadership and motivation variable do not change or have zero value, then consistency value of employee performance of The Regional Financial and Asset Management Agency of Musi Rawas Regency is $\mathbf{3 5 , 3 1 4}$.

b) The regression coefficient of leadership variable (X2) or b1 is $\mathbf{0 , 3 6 5}$. This indicates if the value of leadership variable increases by the amount of one unit, then the value of performance variable will change positively by the amount of $\mathbf{0 , 3 6 5}$ unit. On the other hand, if regression value decreases by the amount of one unit, then employee performance is also predicted to decreases by the amount of 0,365 unit. 
c) The regression coefficient of motivation variable (X3) or b2 is 0,143 which means if the value of motivation variable (X3) increases by the amount of one unit, then performance variable $(\mathrm{Y})$ will change positively by the amount of 0,143 unit. This shows that there is a relationship between leadhersip and motivation with performance as also obtained in (Nugroho et al., 2020).

\section{The significant influence among competence,} leadership, and work motivation on employee performance of The Regional Financial and Asset Management Agency of Musi Rawas Regency

Based on regression calculation, it is obtained that $b 1$ value $=0,241$ and $b_{2}=0,376, b_{3}=0,016$, while a value $=27,277$. These values inputed into multiple linear regression equation as follows: $\mathbf{Y}=\mathbf{2 7 , 2 7 7 +}$ $0,241 \mathrm{X}_{1}+0,376 \mathrm{X}_{2}+0,016 \mathrm{X}_{3}$

The regression equation shows that competence variable (X1), leadership (X2) and work motivation variable (X3) simultaneously influence employee performance. The results can be explained as follows:

a) The constant value is 27,277 which means that if competence, leadership, and work motivation varaibel do not change or have zero value, then the value of employee performance of The Regional Financial and Asset Management Agency of Musi Rawas Regency is 27.277 .

b) The regression coefficient of competence variable (X1) or b1 is 0,241 . This indicates that if the value of competence variable increases by the amount of one unit, then the value of performance variable will change positively by the amount of $\mathbf{0 , 2 4 1}$ unit. On the other hand, if the value of regression decreases by the amount of one unit, then employee performance is also predicted to be declined by the amount of 0,2418 unit. Therefore, it can be concluded that competence has a direct relationship to employee performance.

c) The regression coefficient of leadership variable (X2) or b2 is 0,376 . This indicates that if value of leadership increases by the amount of one unit, then the value of performance variable will change positively by the amount of 0,376 unit. On the other hand, if the value of regression decreases by the amount of one unit, then the employee performance is also predicted to decreases by the amount of 0.376 unit.

d) The regression coefficient of motivation variable (X3) or b3 is 0,016 which means that if the value of motivation variable (X3) increases by the amount of one unit, then performance variable (Y) will increase positively by the amount of
0,016 unit. On the other hand, if the value of regression decreases by the amount of one unit, then employee performance is also predicted to decrease by the amount of 0,016 unit.

e) Simultaneous test (F-test) was conducted to see the influence from independent variable on dependent variable. F-table $=60-3-1=56$, $\mathrm{df}$ $56=2,77$, based on the result of recapulation of multiple linear regression test, it is obtained that the value of $F_{\text {-count }}$ is $9,247>F_{\text {tabel }}=2,77$ and the simultaneous significance level of sig $\mathrm{F}$ is 0,000 . This shows that simultaneously independent variables (competenecy, leadership, and work motivation) have significant influence on dependent variable (performance). This finding is also in agreement with the result in (Nguyen et al., 2020).

\section{Determination of Coefficient $\left(\mathbf{R}^{2}\right)$}

The analysis description for the statistical calculations obtained using SPSS where the data obtained are known to be normally distributed can be seen in Table 7 below:

Tabel 7. The result of coefficient test

\begin{tabular}{ccccc}
\hline \multicolumn{5}{c}{ Model Summary } \\
\hline Model & R & R Square & $\begin{array}{c}\text { Adjusted R } \\
\text { Square }\end{array}$ & $\begin{array}{c}\text { Std. Error of the } \\
\text { Estimate }\end{array}$ \\
\hline 1 & $.576^{\mathrm{a}}$ & .331 & .295 & 6.016 \\
\hline a. Predictors: (Constant), Motivation, leadership, competence
\end{tabular}

The Table 7 above shows that the value of coefficient (R2) is found to be 0,331 . It shows that simultaneously compentency (X1), leadership (X2) and work motivation have an influence on employee performance of The Regional Financial and Asset Management Agency of Musi Rawas Regency of $33,1 \%$, while the rest of $66,9 \%$ influenced by other unexamined variables.

The value of correlation coefficient (R) is 0,576 positve. This can be interpreted that the correlation between independent variables and dependent variable can be said as very high, while a correlation can be said as perfect if the value obtained as 1 with the assumption that other independent variables are constant. The value of determined coefficient (R2) is 0,576 which means that the variation of dependent variable can be explained by all independent variables simultaneously. These results are in line with study result conducted by (Rahardja et al., 2018) which showed that leadership, competence and motivation have significant influence on employee performance. As well as research conducted by (Andriani et al., 2018) which stated that leadership has significant positive influence on teacher performance. These 
results are also in line with theory proposed by (Syakur, Susilo, Wike, \& Ahmadi, 2020) that a leadership can be interpreted as a process of affecting and directing employees to do their tasks and duties.

\section{CONCLUSION}

Based on the result and discussion, it can be concluded that competency, leadership and work motivation have a significant influence on employee performance of the Regional Financial and Asset Management Agency of Musi Rawas Regency. Partially, competence, leadership and motivation have a significant positive effect on the performance of their performances. However, the leadership variable has a dominant effect on performance which is evidenced by the results of the partial regression test that the $b 1$ value for the leadership variable is 0.416 , while the competency variable b1 is 0.380 and the motivation variable b1 is 0.340 . The results of this study have theoretical implications that competence, leadership and motivation affect the performance employee. This work also proves that the leadership variable is also an important factor in improving employee performance. The results are in angreement with the theories explained in (Ahmadi \& Sulistyono, 2019; Andriani et al., 2018; Anwar \& Komariah, 2018; Rahardja et al., 2018; Wibowo, 2016) which states that performance is influenced by various factors including skills, competence, motivation and leadership factors as well as infrastructure and work environment. It is suggested that in the effort of increasing employee performance of the Regional Financial and Asset Management Agency of Musi Rawas Regency, the role of leadership should be utilized as a benchmark for the employees. The evaluation of leader duties also should be carried out periodically.

\section{ACKNOWLEDGMENT}

The author acknowledges the Chancellor of Bina Insan University, Lubuklinggau, South Sumatera and Director of Postgraduate of Management Program for their contributions in helping to the completion of this work.

\section{REFERENCES}

Ahmadi, S. \& Sulistyono, S. (2019). Pengaruh Kompetensi, Kepemimpinan, Dan Disiplin Kerja Terhadap Kinerja Pegawai Di Kantor Pertanahan Kabupaten Bogor. Jurnal Manajemen Kewirausahaan, 15(2), 203-210.
Andriani, S., Kesumawati, N. \& Kristiawan, M. (2018). The influence of the transformational leadership and work motivation on teachers performance. International Journal of Scientific \& Technology Research, 7(7), 1929.

Anwar, E.E. \& Komariah, I. (2018). Manajemen Sumber Daya Manusia. Bandung: Alfabeta.

Ardhani, J. \& Ratnasari, S.L. (2019). Pengaruh Motivasi Kerja Terhadap Kinerja Pegawai Pt. Pln Batam. Jurnal Dimensi, 8(2), 372-385.

Ardiansyah, Y. \& Sulistiyowati, L.H. (2018). Pengaruh kompetensi dan kecerdasan emosional terhadap kinerja pegawai. Jurnal Inspirasi Bisnis dan Manajemen, 2(1), 91100.

Badrianto, Y. \& Ekhsan, M. (2020). Effect of work environment and job satisfaction on employee performance in pt. Nesinak industries. Journal of Business, Management, \& Accounting, 2(1), 85-91.

Basalamah, M.S.A. \& As'ad, A. (2021). The Role of Work Motivation and Work Environment in Improving Job Satisfaction. Golden Ratio of Human Resource Management, 1(2), 94-103.

Budiman, J. \& Barata, J. (2018). Pengaruh Gaya Kepemimpinan Terhadap Pencapaian Akreditasi Institusi Perguruan Tinggi Swasta Di Kalimantan Barat. JURKAMI: Jurnal Pendidikan Ekonomi, 3(2), 58-69.

Dahlan, S. \& Dewasiri, J. (2019). Factors influencing employee performance in leading conglomerate in Sri Lanka. Colombo Journal of Advanced Research, 1(1), 102-129.

Emil, M. \& Albetris, A. (2019). Pengaruh Gaya Kepemimpinan, Budaya Organisasi, dan Lingkungan Kerja Terhadap Kinerja Karyawan Melalui Motivasi pada PDAM Tirta Mayang Kota Jambi. J-MAS (Jurnal Manajemen dan Sains), 4(2), 437-451.

Harahap, S.F. \& Tirtayasa, S. (2020). Pengaruh Motivasi, Disiplin, Dan Kepuasan Kerja Terhadap Kinerja Karyawan Di PT. Angkasa Pura II (Persero) Kantor Cabang Kualanamu. Maneggio: Jurnal Ilmiah Magister Manajemen, 3(1), 120-135.

Kang, E. \& Lee, H. (2021). Employee Compensation Strategy as Sustainable Competitive Advantage for HR Education Practitioners. Sustainability, 13(3), 1049. 
Kim, M. \& Beehr, T.A. (2020). The long reach of the leader: Can empowering leadership at work result in enriched home lives? Journal of occupational health psychology, 25(3), 203.

Krapfl, J.E. \& Kruja, B. (2015). Leadership and culture. Journal of Organizational Behavior Management, 35(1-2), 28-43.

Nguyen, P.T., Yandi, A. \& Mahaputra, M.R. (2020). Factors that influence employee performance: motivation, leadership, environment, culture organization, work achievement, competence and compensation (A study of human resource management literature studies). Dinasti International Journal of Digital Business Management, 1(4), 645-662.

Ngwa, W.T., Adeleke, B.S., Agbaeze, E.K., Ghasi, N. C. \& Imhanrenialena, B.O. (2019). Effect of reward system on employee performance among selected manufacturing firms in the Litoral region of Cameroon. Academy of Strategic Management Journal, 18(3), 1-16.

Novarini, N.N.A., \& Imbayani, I.G.A. (2019). The influence of reward and punishment on employee performance at Royal Tunjung Bali Hotel \& Spa Legian. International Journal of Applied Business and International Management (IJABIM), 4(3), 33-44.

Nugroho, Y.A., Asbari, M., Purwanto, A., Basuki, S., Sudiyono, R.N., Fikri, M.A.A. \& Suroso, S. (2020). Transformational leadership and employees' performances: The mediating role of motivation and work environment. EduPsyCouns: Journal of Education, Psychology and Counseling, 2(1), 438-460.

Parashakti, R.D., Fahlevi, M., Ekhsan, M.\& Hadinata, A. (2020). The influence of work environment and competence on motivation and its impact on employee performance in health sector. Paper presented at the 3rd Asia Pacific International Conference of Management and Business Science (AICMBS 2019).

Pasae, P. (2021). The Influence of Human Resource Competence Factors on Employee Work Performance. Point Of View Research Management, 2(3), 151-160.

Prestia, A. S. (2021). The remote influence of nursing leadership. Nurse Leader, 19(2), 184-187.

Rahardja, U., Moein, A. \& Lutfiani, N. (2018). Leadership, competency, working motivation and performance of high private education lecturer with institution accreditation B: Area kopertis IV Banten province. Man India, 97(24), 179-192.

Santoso, N.B.A., \& Riyanto, S. (2020). The Effect of Work Motivation, Organizational Commitment, and Job Satisfaction on the Contract Employees Performance of $\mathrm{Pt}$ Bank Rakyat Indonesia Branch Office of Jakarta Daan Mogot. International Journal of Innovative Science and Research Technology, 5(1), 561-568.

Sunaryo, A., Hardhienata, S. \& Suhardi, E. (2020). Improving Teacher Performance Through Strengthening Transformational Leadership, Pedagogical Competence And Organizational Commitment (Empirical Study Using Correlational Approach And Sitorem Analysis In Paud Teachers In Bogor City, West Java Province). PalArch's Journal of Archaeology of Egypt/Egyptology, 17(6), 7795-7803.

Suratman, S., Arafat, Y. \& Eddy, S. (2020). The Influence of Principal's Leadership and Teacher's Competence toward Teacher's Performance in Indonesia. Journal of Social Work and Science Education, 1(2), 96-104.

Syakur, A., Susilo, T.A.B., Wike, W. \& Ahmadi, R. (2020). Sustainability of Communication, Organizational Culture, Cooperation, Trust and Leadership Style for Lecturer Commitments in Higher Education. Budapest International Research and Critics Institute (BIRCI-Journal): Humanities and Social Sciences, 3(2), 1325-1335.

Tarigan, N.M.R., \& Setiawan, H. (2020). The Effect of Employee Competence on Increasing Employee Motivation in Sumut Bank of Sharia Unit, North Sumatera. Budapest International Research and Critics Institute (BIRCI-Journal): Humanities and Social Sciences, 3(2), 858-867.

Top, C., Abdullah, B.M.S., \& Faraj, A.H.M. (2020). Transformational leadership impact on employees performance. Eurasian Journal of Management \& Social Sciences, 1(1), 49-59.

Wahyuni, N.P.D., Purwandari, D.A. \& Syah, T.Y.R. (2020). Transactional Leadership, Motivation and Employee Performance. Journal of Multidisciplinary Academic, 3(5), 156-161.

Wibowo. (2016). Manajemen Kinerja. Jakarta: PT. Rajagrafindo Persada. 